\title{
Comparative Law by Numbers? Legal Origins Thesis, Doing Business Reports, and the Silence of Traditional Comparative Law
}

The legal origins thesis-the thesis that legal origin impacts economic growth and the common law is better for economic growth than the civil law-has created hundreds of papers and citation numbers unheard of among comparative lawyers. The Doing Business reports-cross-country comparisons including rankings on the attractiveness of different legal systems for doing business-have the highest circulation numbers of all World Bank Publications; even critics admit that they have been successful at inciting legal reform in many countries in the world. Yet, traditional comparative lawyers have all but ignored these developments.

This ignorance has at least three negative consequences. First, the economic debate will continue to ignore or misrepresent traditional comparative law knowledge if we do not bring our specific knowledge to the table. Second, comparative law as a discipline misses the opportunity to measure its own progress and shortcomings in view of a literature which, although on its face radically different, provides important challenges. This concerns especially the promises and shortcomings of interdisciplinarity. Third, and perhaps most importantly, our silence means that comparative law as a field remains (or increasingly becomes) irrelevant for political projects because its themes are discussed more and more by others. If we comparative lawyers want to retain (or regain) relevance, we need to bring our particular expertise to bear on projects as important as law reform.

The first purpose of this essay is to introduce the legal origins literature to traditional comparative law and to show important con-

* Professor of Law, Duke University; Visiting Research Fellow 2009-10, Program for Law and Public Affairs, Princeton University. This essay is based on remarks made at an AALS panel that the interest groups on comparative law and on law and economics jointly organized in January 2009 in order to spur a dialogue between lawyer-economists and comparative lawyers on this literature. I thank Ed Morrison, 2008 chair of the law and economics interest group, for the smooth coorganization of the panel, and Richard Buxbaum, Vivian Grosswald Curran, Bénédicte Fauvarque-Cosson, Anne-Julie Kerhuel, Curtis Milhaupt, John Reitz, and Holger Spamann for their participation in the panel and/or this issue. Thanks for advice on earlier versions of this essay go to Mitu Gulati, Mathias Reimann, and John Reitz. 
nections to the traditional themes of our discipline. A second purpose is to examine both what particular critique of this literature emerges from the knowledge of traditional comparative law and where traditional comparative law itself can learn from this literature. A third purpose, finally, is to consider the continuing relevance of comparative law. Will it be replaced by economics and statistics? Or is there a value specific to comparative law that cannot be supplanted?

\section{INTRODUCTION}

What is the most important development in comparative law you have never heard of? If you are a traditional comparative lawyer, chances are the answer is: the legal origins thesis and the Doing Business reports. The legal origins thesis-the thesis that the common law is better for economic growth than the civil law-has created hundreds of papers and citation numbers unheard of among comparative lawyers. ${ }^{1}$ The Doing Business reports-cross-country comparisons including rankings of the attractiveness of different legal systems for doing business-have the highest circulation numbers of all World Bank Publications; even critics admit that they have been successful at inciting legal reform in many countries in the world.

It should be obvious that both the legal origins thesis and the Doing Business reports are of the highest interest for comparative law. They take on central issues of our discipline: the difference between civil and common law, the transplantation of laws, the functionality of different laws. Indeed, lawyers have responded. There have been significant reactions from commercial law scholars, some of whom have accepted the thesis of the superior common law with little trepidation. ${ }^{2}$ There have also been reactions from the (reemerging) field of law and development. ${ }^{3}$ Finally, area studies, in particular experts on Asian law, have provided mostly critical responses. ${ }^{4}$ Traditional comparative lawyers by contrast, seem to think that this debate research has nothing to do with us. ${ }^{5}$ Comparative

1. Mathias Siems, Book Review, 12 Ed. L. Rev. 334 (2008).

2. For a more critical perspective, see Mark Roe, Legal Origin and Modern Stock Markets, 120 HARV. L. REV. 460 (2006) (arguing for politics instead of legal origins as causal factor).

3. See also the contributions to a forthcoming symposium issue of the Brigham Young University Law Review on the topic "Evaluating Legal Origins Theory."

4. E.g. John K.M. Ohnesorge, Developing Development Theory: Law and Development Orthodoxies and the Northeast Asian Experience, 28 U. PA. J. INT'L Econ. L. (2007); Curtis Milhaupt, Beyond Legal Origin: Rethinking Law's Relationship to the Economy-Implications for Policy, 57 Aм. J. Comp. L. 831 (2009); and the famous spoof by Mark West, Legal Determinants of World Cup Success (2002), http://ssrn. com/abstract $=318940$.

5. The most comprehensive exceptions are Mathias Siems, Legal Origins: Reconciling Law \& Finance and Comparative Law, 52 McGiLl L.J. 55 (2007); Mathias Siems, Statistische Rechtsvergleichung, 37 RABELSZ 354 (2008). 
law textbooks do not mention the new literature at all. Even more strikingly, comparative law texts on special subjects-legal families and traditions, comparative law and economics, legal transplants and reception-almost unanimously ignore this literature. This is true for survey texts in comparative law encyclopedias and handbooks, but also for the vast majority of other books and articles.

One can speculate about the reasons for this omission: the literature may not be known; it may be considered to belong to economics rather than to comparative law; it may be viewed as so seriously deficient that it does not even deserve mentioning. Be that as it may, this ignorance has at least three negative consequences. First, the economic debate will continue to ignore or misrepresent traditional comparative law knowledge if we do not bring our specific knowledge to the table. Second, comparative law as a discipline misses the opportunity to measure its own progress and shortcomings in view of a literature which, although on its face radically different, provides important challenges. This concerns especially the promises and shortcomings of interdisciplinarity. Third, and perhaps most importantly, our silence means that comparative law as a field remains (or increasingly becomes) irrelevant for political projects because its themes are discussed more and more by others. If we comparative lawyers want to retain (or regain) relevance, we need to bring our particular expertise to bear on projects as important as law reform.

The first purpose of this essay is to introduce the legal origins literature to traditional comparative law and to show important connections to the traditional themes of our discipline. A second purpose is to examine both what particular critique of this literature emerges from the knowledge of traditional comparative law and where traditional comparative law itself can learn from this literature. A third purpose, finally, is to consider the continuing relevance of comparative law. Will it be replaced by economics and statistics? Or is there a value specific to comparative law that cannot be supplanted?

The article first presents the academic legal origins literature and the Doing Business reports of the World Bank, as well as reactions to both and responses to these reactions (II). In the next, main, section, it discusses connections between the literature and several themes of traditional comparative law: the functional method and the common core approach, the role of legal families and traditions, the problem of commensurability and evaluation of legal systems, and the issues of legal transplants and law reform (III). Finally, the article discusses what comparative law can learn from the new methods discussed and from their astonishing political success (IV). 


\section{From Legal Origins to Doing Business}

\section{A. Legal Origins}

\section{Presentation}

The so-called legal origins thesis has emerged from the work, since 1997, of a relatively small number of economists, often referred to by their last name initials as LLSV or LLS. The thesis was first developed in the comparably narrow area of investor protection. ${ }^{6}$ It has since been broadened into a theory that contains essentially two elements.

The first element is that "law matters": legal institutions have an impact on economic growth. This is in tune with neoclassical law and economics, which is based essentially on the idea that law should be measured by the incentives it sets for welfare-maximizing conduct. In this generality, the idea sounds uncontroversial, particularly to lawyers who believe, as do comparatists following Zweigert and Kötz, that what matters about the law is its functionality ${ }^{7}$ and that "law is social engineering." 8 Yet the idea of legal engineering was doubtful already in the 1960s (i.e., around the time when Konrad Zweigert developed his methodology) among members of the first law and development school-mainly lawyers-who were frustrated with the limited success of law reform. ${ }^{9}$ More recently, however, faith in the transformative power of law has been revived, especially among economists. ${ }^{10}$ Still, there remains a methodological problem: even if rich countries have better laws, it is hard to determine whether these countries are rich because they have good laws and institutions, or whether they have good laws and institutions because they are rich

6. Rafael La Porta, Florencio Lopez de Silanes, Andrei Shleifer, \& Robert W. Vishny, Legal Determinants of External Finance, 52 J. OF FinAnce 1131 (1997); Rafael La Porta, Florencio Lopez de Silanes, Andrei Shleifer, \& Robert W. Vishny, Law and Finance, 106 J. Pol. ECON. 1113 (1998).

7. Konrad Zweigert \& Hein Kötz, An Introduction to Comparative Law 34 (3d ed. 1996); for the epistemological basis, see Ralf Michaels, The Functional Method of Comparative Law, in The Oxford Handbook of Comparative Law 339, 364-66 (Mathias Reimann \& Reinhard Zimmermann eds., 2006).

8. ZweigerT \& Kötz, id. at 45 (3d ed. 1996). The earliest version of the chapter with the "current trends in legal science" (id.) it describes dates from 1960: Konrad Zweigert, Méthodologie du droit comparé, in I MéLAnges offerts À Jacques MaURY 579 (1960). The idea of the lawyer as social engineer is borrowed from the early days of sociological jurisprudence; see Roscoe Pound, The Theory of Judicial Decision, 36 Harv.L.Rev. 940, 954-58 (1923). See now also Legal Engineering AND Comparative LAw (2 Vols., Eleanor Cashin-Ritaine ed., 2008-09).

9. The classical U.S. account is David Trubek \& Marc Galanter, Scholars in SelfEstrangement: Some Reflections on the Crisis in Law and Development Studies in the United States, 1974 WIS. L. REv. 1062; see also John Henry Merryman, Comparative Law and Social Change: On the Origins, Style, Decline and Revival of the Law and Development Movement, 25 Aм. J. Comp. L. 457 (1977); and now Kevin E. Davis \& Michael J. Trebilcock, The Relationship between Law and Development: Optimists versus Skeptics, 56 Aм. J. Comp. L. 895, esp. 915-38 (2008).

10. Davis \& Trebilcock, supra note 9, at 898-915. 
and can afford them, or whether both wealth and good laws are both due to some third factor. ${ }^{11}$ Law is so interwoven with society that it cannot easily be separated. This is, of course, a challenge also for comparative law, especially for the functional method. ${ }^{12}$ The ingenious idea of LLSV was to look at settings in which law was not cooriginal with society but instead was imposed as an external factor. They found such settings in the context of colonization, where law was not imported by local power elites but instead imposed externally by the colonizing power, with a random distribution of different legal systems depending on which European country colonized parts of the non-European world.

This research led LLSV to the second important element of their theory: legal origins matter. The legal institutions are a function of the origins of the legal system, in particular in the civil law or the common law tradition. Taking these two elements together, this means that legal origin impacts economic growth. More controversially, countries that adopted the common law perform, overall, better than those with a civil law origin. Two types of reasons are given for the superiority of the common law over the civil law. ${ }^{13}$ One reason (the "political channel") is that judges are said to be more independent in common law than in civil law systems, so that the government has less influence on market developments. The other reason (the "adaptability channel") is that the common law, with its foundation in the development of case law rather than in legislative texts, is deemed more adaptive to changing societal requirements.

\section{Reactions and Developments}

The impact of this line of research has been enormous. Over time, its authors have expanded their focus from the original relatively narrow field of investor protection to a wide variety of areas, as seen in the graph on page 770 . The thesis and the underlying research contributed two new fields-law and finance, and new comparative economics ${ }^{14}$ - that have been joined by an enormous number of scholars. Their ideas have also been picked up by lawyers.

11. Holger Spamann, Large-Sample, Quantitative Research Designs for Comparative Law?, 57 Am. J. Comp. L. 797, at 806 (2009); for a survey of attempts to overcome the problem, see Andrew Williams \& Abu Siddique, The Use (and Abuse) of Governance Indicators in Economics: A Review, 9 ECON. OF Governance 131, 150-52 (2008).

12. E.g. Günter Frankenberg, Critical Comparisons: Re-thinking Comparative Law, 26 HARV. INT'L L.J. 411, 440 (1985).

13. Thorsten Beck, Asli Demirgüç-Kunt \& Ross Levine, Law and Finance: Why does Legal Origin Matter?, 31 J. Comp. Econ. 653 (2003).

14. Simeon Djankov et al., The New Comparative Economics, 31 J. Comp. Econ. 595 (2003); Bruno Dallago, Comparative Economic Systems and the New Comparative Economics, 1 Eur. J. Comp. Econ. 59 (2004); Peter J. Boettke et al., The New Comparative Political Economy, 18 Rev. Austr. Econ. 281 (2005). 
Institution

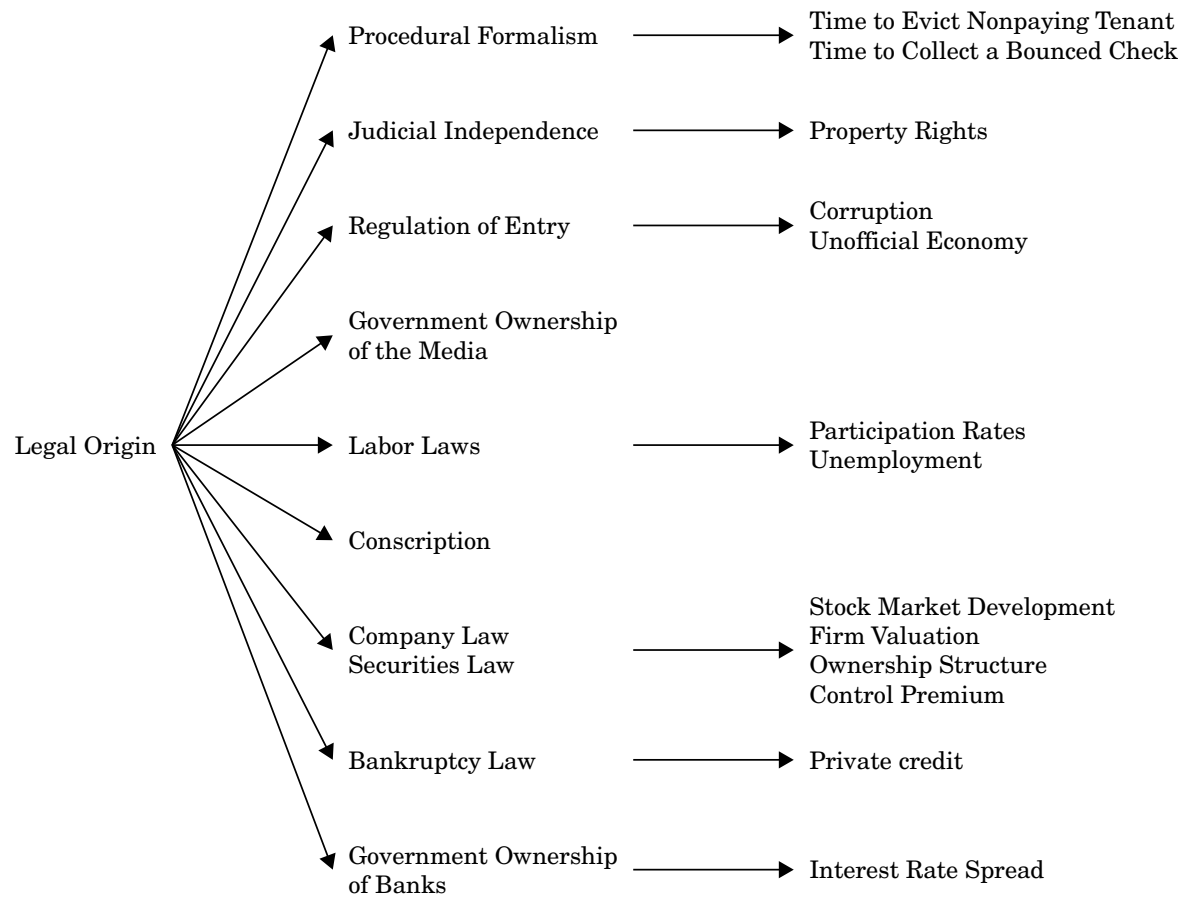

Outcomes

La Porta et al. (2008) at 292

At the same time, almost every element of the original thesis has come under serious attack. In particular, the coding of countries investigated is being criticized-the 1997 paper has been shown to rest on erroneous coding; properly recoded, the superiority of common law origins could no longer be demonstrated. ${ }^{15}$ Also, the thesis that legal origins are truly exogenous to legal systems turned out to be problematic. ${ }^{16}$ Finally, the claim that the common law causes growth has been criticized so heavily that LLS themselves now appear to back off from it to some extent.

In response to such criticism, three authors of LLS co-authored an extremely accessible survey article on the legal origins thesis. ${ }^{17}$ In this article, they accept some of the criticism but maintain the essential elements of their original thesis. Most importantly, they reject alternative explanations that legal origins are merely proxies for

15. Holger Spamann, The 'Anti-Director Rights Index' Revisited, REv. Fin. Stud. Advance Access published Sept. 14, 2009. doi:10.1093/rfs/hhp067.

16. John Armour et al., How Do Legal Rules Evolve? Evidence from a Cross-Country Comparison of Shareholder, Creditor and Worker Protection, 57 Aм. J. Comp. L. 579 , at 591-92 (2009).

17. Rafael La Porta et al., The Economic Consequences of Legal Origins, $46 \mathrm{~J}$. ECON. LiT. 285 (2008). 
other, non-legal factors, especially culture, politics, and history. In the process, however, their understanding of legal origins has become very broad; it now encompasses human capital and the beliefs of the respective participants. The authors now define "[l]egal origins as a style of social control of economic life" where "common law stands for the strategy of social control that seeks to support private market outcomes, whereas civil law seeks to replace such outcomes with state-desired allocations." 18 This suggests that what the authors are looking for is, ultimately, something other than law.

\section{B. Doing Business Reports}

\section{The Reports}

The legal origins thesis has had a lot of influence, but nowhere more than through its adoption by the World Bank for its Doing Business reports. As early as 2002, the World Bank took up the finding of the Legal Origins thesis that the common law is more conducive to economic growth. ${ }^{19}$ Beginning in 2004, the International Finance Corporation (IFC), a member of the World Bank Group, has been issuing annual reports that measure and compare the "ease of doing business" in more than 130 countries worldwide. The first report addressed five types of business activity; this list has been expanded to ten activities since the 2007 report. ${ }^{20}$ Led by Simeon Djankov, a frequent coauthor with LLS (and now Bulgarian finance minister and deputy prime minister), the reports rely strongly (though not, of course, exclusively) on the legal origins thesis and its literature. ${ }^{21} \mathrm{Al}-$ though the reports measure the attractiveness for investors rather than economic growth, their relevance for economic success is quite obvious. $^{22}$

The Doing Business reports have given the legal origins thesis a distribution forum, access to funding for its expensive surveys, and the reputation of the World Bank. Indeed, the reports have become

18. Id. at 286. As early as 1998 , the authors used "legal traditions as cruder proxies for the political orientation of governments." La Porta et al., The Quality of Government, 15 J. OF L., EcON. \& ORG. 222, 232 (1999).

19. World Bank, Legal and Judicial Reform: Observations, Experiences and Approach of the Legal Vice Presidency 20 (2002), as quoted in Frank H. Stephen \& Stefan Van Hemmen, Laws, Enforcement, Legality, and Economic Development, 26 WASH. U. J.L. \& POL'y 37, 46-47 (2008).

20. Starting a business; dealing with licenses (later changed to "dealing with construction permits"); hiring and firing workers (later changed to "employing workers"); registering property; getting credit; protecting investors; paying taxes; trading across borders; enforcing contracts; closing a business.

21. See Doing Business 2004-Understanding Regulations, xiv.

22. See, e.g., DoIng Business 2004, id. at 83 ("Heavier regulation of business activities generally brings bad outcomes, while clearly defined and well-protected property rights enhance prosperity"). For criticism, see Amanda Perry-Kessaris, Finding and Facing Facts about Legal Systems and Foreign Direct Investment in South Asia, 23 Leg. Stud. 649 (2003). 
the most-circulated series issued by that institution. They are actively marketed: they have their own website and blog and even a presence on Facebook; the annual reports for 2008 and 2009 were virtually launched on Second Life. Yet, the Doing Business reports display a number of crucial changes from the academic literature that underlies them. First, whereas the findings of the legal origins literature are confined to empirical research and descriptive and analytical statements, the Doing Business reports are aimed at decision makers. One part of their intended audience are international investors. Yet their main goal is to spur reform in countries that are found to be deficient. Indeed, the ten best reforming countries from one year to the next are joined as the "reformers club" and feted by the World Bank. A second important change is the decision, since the second annual report in 2005, to rank the various countries based on how they perform with regard both to individual activities and overall. In these rankings, the legal origins thesis is confirmed: among the ten top-ranked countries in the 2009 report are eight common law and two Scandinavian nations. Traditional civil law countries perform relatively badly: Switzerland as the strongest continental European legal system is ranked at 21 (behind Malaysia); France is now ranked at 31 (two ranks ahead of Azerbaijan it was ranked as low as 47th in the 2005 report. Nonetheless, the IFC is eager to point out that civil law countries can perform well on any of the indices.

\section{Reactions and Developments}

The Doing Business reports have had enormous impact. Governments reacted by emphasizing reform. For example, the Rwandan President established, in 2007, a national Doing Business Unit with the explicit goal of improving the country's rankings-and indeed, Rwanda is now the "top performer," having moved from the 163rd to the 67th rank in the 2010 report. Dubai established an International Financial Centre governed by common law because that was perceived as more attractive for investors. ${ }^{23}$ Whether private investors also rely on the reports and especially on the rankings is less clear.

At the same time, the Doing Business reports have been controversial from the beginning. Three types of criticism are particularly relevant here. A first significant criticism comes from economists and concerns the methodology, in particular of the ranking methodology. Economists point out, amongst others, that the minute differences between the data for differently ranked countries do not allow meaningful assessments on individual rankings, especially in view of the great differences between countries and economies otherwise. Moreo-

23. Michael Strong \& Robert Himber, The Legal Autonomy of the Dubai International Financial Centre: A Scalable Strategy for Global Free Market Reforms, 29 Economic Affairs Issue 2, 36 (June 2009). 
ver, economists have argued that the method will induce countries to improve their rankings rather than address the actual problems. ${ }^{24}$

A second criticism is substantive; it is directed against a perceived preference for deregulation over other values-one being solidarity and justice, the other being culture. ${ }^{25}$ Especially controversial was use of an "employing workers indicator" (EWI) that measures, in essence, how easy it is to hire and fire. Not surprisingly, labor organizations, in particular the International Trade Union Confederation and the International Labor Organization, criticized what they viewed as a one-sided focus on efficiency at the expense of interests in labor. ${ }^{26}$ Critics suggested that countries are actually rewarded if they do not ratify pertinent ILO conventions. In 2008, even the IMF ordered its staff not to use the EWI. The U.S. Congress has recently asked the U.S. representative to the World Bank to work towards suspension of the use of the "Employing Workers' Indicator" in its current form for the purpose of ranking or scoring country performance. ${ }^{27}$

A third criticism, directed already at the legal origins thesis but voiced with more emphasis against the Doing Business reports, is specifically legal and concerns the insufficient understanding of law. Within the World Bank, lawyers were highly critical of the nonchalant treatment of their discipline by economists, a criticism that mirrors a widely held perception of the different roles of lawyers and economists within the World Bank. ${ }^{28}$ Outside the World Bank, French lawyers in particular were shocked by the low ranking that France received in the survey and the poor understanding the report showed, in their view, of French law. The Association of the Friends of French Legal Culture published two reports-one co-authored by French members of the association, one compiling reactions from for-

24. Bjørn Høyland et al, Be careful when Doing Business (2008), available at http://www.ifiwatchnet.org/sites/ifiwatchnet.org/files/Doing\%20Business_ESOPanalysis.pdf; Benito Arruñada, Pitfalls to Avoid when Measuring Institutions: Is Doing Business Damaging Business?, J. Comp. Econ. 729 (2007). The Independent Evaluation Group did not find evidence of such reactions. WORLD BANK INDEPENDENT Evaluation Group (IEG), infra note 34, at 19, 46, 65-66 (2008).

25. For a survey of literature, see Sangheon Lee et al., The World Bank's Employing Workers" Index: Findings and Critiques-A Review of Recent Evidence, 147 InT'L LABour REv. 416 (2008). For an alternative proposal, see Alvaro Santos, Labor Flexibility, Legal Reform and Economic Development, 50 VA. J. INT'L L. (forthcoming 2009).

26. ITUC welcomes World Bank's suspension of "Doing Business" labour indicator, available at http://www.ituc-csi.org/spip.php?article3505; ILO, World Bank Doing Business report: The employing workers indicator (GB.300/4/1) (2007), available at http://www.ilo.org/wcmsp5/groups/public/_-ed_norm/_-relconf/documents/meeting document/wcms_085125.pdf;.

27. H.R. Rep. No. 111-151, at 44-45 (2009) (Conf. Rep.).

28. Alvaro Santos, The World Bank's Use of the "Rule of Law" Promise in Economic Development, in The New Law and Economic Development. A Critical Appraisal 253, 278-95 (David M. Trubek \& Alvaro Santos eds., 2006); Galit Sarfaty, Why Culture Matters in International Institutions: The Marginality of Human Rights at the World Bank, Am. J. INT'L L. (forthcoming). 
eign members-severely criticizing the Doing Business report 2004. ${ }^{29}$ Numerous other French scholars and institutions joined in. A new research institute was established to demonstrate the attractiveness of French law. ${ }^{30}$ (Somewhat typically, almost all of these contributions were published in French, ${ }^{31}$ leaving them with almost no impact in the international sphere.) There is less debate in Germany, though a couple of German legal scholars have also presented critical responses. ${ }^{32}$ Bar associations in the United Kingdom and in Germany have also begun to market their laws more aggressively. ${ }^{33}$

Such criticism from both outside and within the World Bank has led to an appraisal of the Doing Business project by the Independent Evaluation Group, a unit within the World Bank Group. ${ }^{34}$ The report, based on a literature review, analysis of ratings and underlying data published by the Doing Business reports, and interviews with World Bank and IFC staff as well as country officials and experts, emphasizes some of the criticism voiced in the discussion before, especially regarding the use of the employing workers indicator ${ }^{35}$ and the ranking method. ${ }^{36}$ (Still, the report also recognizes how effective cross-country rankings are for spurring dialogue and for motivating interest and action, and it proposes that the World Bank use such rankings for other projects.) The report also questions the correlation between ease of business and overall economic performance. The report is more ambivalent about the legal origins thesis. ${ }^{37}$ On the one

29. Association Henri Capitant des amis de Law Culture juridique franCAISE, LES DROITS DE TRADITION CIVILISTE EN QUESTION. A PROPOS DES RAPPORTS DoING Business (2 Vols, 2006); see Bénédicte Fauvarque-Cosson \& Anne-Julie Kerhuel, Is Law an Economic Contest? French Reactions to the Doing Business World Bank Reports and Economic Analysis of the Law, 57 Am. J. Comp. L. 811, 820-24 (2009).

30. Http://www.gip-recherche-justice.fr/aed.htm.

31. An exception is Ménard \& du Marais, infra note 45; published in an earlier version in New Frontiers of LaW and Economics. First International Scientific Conference on Law and Economics at the University of St. Gallen 7 (2006).

32. Very critically Christoph Kern, Justice Between Simplification and ForMalism (2007); Christoph Kern, Die Doing-Business-Reports der Weltbank fragwürdige Quantifizierung rechtlicher Qualität?, 64 JURISTENZEITUNG 498 (2009); somewhat more positive is Mathias M. Siems, What Does not Work in Comparing Securities Laws, A Critique on La Porta et al.'s Methodology, InT'L Comp. \& Com. L. Rev. 300 (2005); Mathias M. Siems, Numerical Comparative Law-Do we Need Statistical Evidence in Law in Order to Reduce Complexity?, 13 CARD. J. InT. Comp. L. 521 (2006); Siems, supra note 5.

33. See England and Wales: The Jurisdiction of Choice (2008), available at http://www.lawsociety.org.uk/documents/downloads/jurisdiction_of_choice_brochure. pdf; LAW-MADE IN GERMANY (2008), available at http://www.lawmadeingermany.de/ Law-Made_in_Germany.pdf; see also Otfried Höffe, Die Alte Welt im Recht, FrankFurter Allgemeine Zeitung, 18 May 2009, 71; Horst Eidenmüller, Recht als Produkt, 64 JuRistenzeITUNG 641 (2009).

34. World Bank Independent Evaluation Group (IEG), Doing Business: An Independent Evaluation. Taking the Measure of the World Bank-IFC Doing Business IndicAToRs (2008).

35. Id. at $33-34,52$.

36. Id. at $18-19,52,61-66$.

37. Id. at $24-26,69-75$. 
hand, it accepts both the causal role of legal origins for many indicators and the findings that civil law systems perform worse. On the other hand, the report emphasizes that "civil law countries can still score well on the [Doing Business] indicators" and even points out, somewhat bizarrely, that "[i]f a hypothetical civil law economy were constructed combining the scores of the highest-scoring civil law country on each indicator, it would place third in the overall ranking." 38 Given the enormous differences between the highest-ranking civil law countries, it is hard to conceive of such a hypothetical economy.

In response to the independent evaluation, the Doing Business Group at first altered its method only slightly. ${ }^{39}$ A more dramatic step followed earlier this year when the Group announced that it would henceforth reward countries for complying with relevant ILO Conventions under the assumption "that well-designed worker protections are of benefit to the society as a whole" and that it would remove the Employing Workers Indicator (EWI) as incompatible with World Bank policy, and possibly replace it with a worker protection indicator that could cover matters such as the extent to which a country is adhering to core international labor standards. ${ }^{40}$ This change, explained at greater length in the Doing Business 2010 report, ${ }^{41}$ represents a significant shift in focus away from efficiency towards a broader vision of the project. It can be presumed that the change was a reaction to external pressure rather than a result of internal processes. ${ }^{42}$

\section{Some Comparative Law Themes}

What should we comparative lawyers make of all this? The authors of both the legal origins thesis and the Doing Business reports are all economists (and "lawyer wannabes," as one of them put it) ${ }^{43}$ who aim their project at comparative economics, not comparative

38. World Bank Independent Evaluation Group, supra note 34, at 26.

39. Http://www.doingbusiness.org/MethodologySurveys/MethodologyNote.aspx, criticized as insufficient by Benito Arruñada How Doing Business Jeopardizes Institutional Reform (2008), available at http://ssrn.com/abstract=1143312. For earlier changes to the method, see http://www.doingbusiness.org/MethodologySurveys/ MethodologyNoteArchive.aspx.

40. Revisions to the EWI Indicator, available at http://www.doingbusiness.org/ documents/EWI_revisions.pdf.

41. See now Doing Business 2010-Reforming Through Difficult Times.

42. For an analysis still very much in tune with deregulation, see Simeon Djankov \& Rita Ramalho, Employment Laws in Developing Countries, 37 J. Comp. Econ. 3 (2009). Cf. Joshua C. Hall \& Peter T. Leeson, Good for the Goose, Bad for the Gander: International Labor Standards and Comparative Development, 28 J. LABor RESEARCH 658 (2007).

43. Florencio Lopez-de-Silanes, as quoted in Nicholas Thompson, Common Denominator, LEGAL AFFAIRS Jan./Feb. 2005, available at http://www.legalaffairs.org/ issues/January-February-2005/feature_thompson_janfeb05.msp. 
law. Nonetheless, there are a number of noteworthy connections with comparative law projects.

\section{A. Comparative Law Method}

The economic and statistical approach endorsed by the legal origins literature and the Doing Business reports has, at first sight, little in common with traditional comparative law. Yet, a second look reveals interesting parallels with the emphasis in comparative law on law in action and with two core methods of our discipline: the functional method and the common core approach.

\section{Law in the Books and Law in Action}

Early texts in the legal origins literature focused merely on legal rules, with little attention paid to how they are applied in practice. ${ }^{44}$ This focus on formal law was clearly deficient from a comparative law perspective, which has long emphasized the importance of law in action over law in the books and on how law is applied in fact as opposed to merely what its rules say. 45 The focus on formal law was especially puzzling in economics given its focus on real world development; it can only be explained by the deficient understanding of law that prevails in so many neighbor disciplines. Indeed, the focus in the legal origins literature has been broadened: interviews are now directed at how legal rules play out in fact, and the understanding of law includes its enforcement. However, as we have known in comparative law, this adds significant complexity to the analysis, both in its descriptive and in its normative variants. Changing legal rules is easy, but it is also mostly ineffective, as the earlier law and development experience has shown. The actual application of law and people's attitudes towards that law are much harder to change; they are also-this is important for the legal origins literature-harder to measure. Thus, when LLS now proclaim that "transplantation involves not just specific legal rules . . . but also legal institutions . . . human capital of the participants in the legal system, and crucially the strategy of the law for dealing with new problems," 46 they paint a

44. La Porta et al., Law and Finance, supra note 6, at 1140, focus on enforcement because "a strong system of legal enforcement could substitute for weak rules, since active and well-functioning courts can step in and rescue investors abused by the management." However, in that study, they only look generally at the strength of the rule of law and similar macrocomparative aspects, not at the specific enforcement of the particular legal rules under review.

45. Claude Ménard \& Bertrand du Marais, Can we Rank Legal Systems According to their Economic Efficiency?, 26 WASH. U. J.L. \& PoL'Y 55, 72-75 (2008); see generally Mathias Reimann, The Progress and Failure of Comparative Law in the Second Half of the Twentieth Century, 50 Aм. J.Comp.L. 671, at 675-76, 679-80 (2002). See already David Campbell \& Sol Piciotto, Exploring the Interaction between Law and Economics: The Limits of Formalism, 18 LEG. STUD. 249, 262-66 (1998).

46. La Porta et al., supra note 17, at 307. 
somewhat unrealistic picture of legal transplants. The problem is that, more often than not, transplantation does not involve human capital. ${ }^{47}$ Moreover, the authors' conviction that "beliefs and ideologies become incorporated in legal rules, institutions, and education and, as such, are transmitted from one generation to the next" displays, in the end, an undue faith in the power of formal rules. Twentieth-century Germany, to use but one example, has seen five political regimes with radically different ideologies, while core legal rules, institutions, and education remained remarkably similar. ${ }^{48}$ If we have learned anything in comparative law, it is that legal rules alone are compatible with a wide variety of ideologies, and that law reform must go much farther than just the adoption of rules.

\section{Functional Method}

At its core, the economic method used by the legal origins literature and the Doing Business reports is really a quantitative refinement of the functional method. ${ }^{49}$ The proximity between functionalist comparative law and economics has been recognized before: economic efficiency can serve as a benchmark against which legal systems are measured. ${ }^{50}$ This is the case when Henry Hansmann and Ugo Mattei analyze the trust under U.S. law and compare it to solutions under European civil law; 51 when Hein Kötz uses economic arguments of the cheapest risk avoider and the cheapest risk insurer to compare English and German law on unfair terms in consumer contracts; ${ }^{52}$ or when Aristides Hatzis shows for various areas of contract law how "the solution provided by the civil law systems . . . is more congenial to the one advocated by economists as the most efficient one."53 In this literature, however, economic efficiency is established in the abstract and usually provides no more than a starting point for debate. The legal origins literature by contrast, promises not only empirical data but also embraces a broader scope of

47. Cf. Curtis J. Milhaupt \& Katharina Pistor, Law \& Capitalism: What Corporate Crises Reveal about Legal Systems and Economic Development around THE WORLD 210-12 (2008).

48. See DAs BGB im Wandel der Epochen (Uwe Diederichsen \& Wolfgang Sellert eds., 2002); Joachim Rückert, Das BGB und seine Prinzipien: Aufgabe, Lösung und Erfolg, in I Historisch-Kritischer Kommentar zUM BGB 34 (2003).

49. Michaels, supra note 7 , at 354 with references.

50. See Ralf Michaels, The Second Wave of Comparative Law and Economics?, 59 U. Toronto L. J. 197, 199 (2009) with references.

51. Henry Hansmann \& Ugo Mattei, The Functions of Trust Law: A Comparative Legal and Economic Analysis, 73 N.Y.U. L. REv. 434 (1998).

52. Hein Kötz, Unfair Terms in Consumer Contracts. Recent Developments in Europe from a Comparative and Economic Perspective, in Festskrift til Ole Lando 203 (Lynge Andersen ed., 1997). The basis for the least-cost risk avoider and least-cost risk insurer considerations is Guido Calabresi, The Cost of Accidents (1970).

53. Aristides N. Hatzis, Civil Contract Law and Economic Reasoning-An Unlikely Pair?, in The architecture of European Codes And Contract Law 159, 175 (Stefan Grundmann \& Martin Schauer eds., 2006). 
functions of law. Laws are compared with regard to multiple immediate functions and one overall function. The immediate functions all concern the facilitation of individual economic conduct: establishing a corporation, evicting a delinquent tenant, firing employees. The overall function is to provide economic growth.

One frequent criticism of functionalist comparative law can be directed against the legal origins literature as well: the assumption that legal institutions necessarily perform certain functions and that certain functions make certain laws necessary. ${ }^{54}$ The function of courts is to enforce contracts; the enforcement of contracts requires effective courts. Other functions of legal rules are ignored: warning functions of formal requirements, social protection in tenancy and employment laws, etc. Functional equivalents-other institutions, legal or non-legal, that perform the same function-are ignored as well. ${ }^{55}$ Perhaps the function of minority shareholder protection, which is performed by unblocked shares in the common law, is performed by other means in Germany. ${ }^{56}$ Perhaps the role of courts in developing the law is performed by legislators in France and scholars in Germany, so that the difference in the respective ability of legal systems to evolve is smaller than assumed by the legal origins scholars. ${ }^{57}$ Perhaps the formalities in French law on the transfer of property in land must be compared with title insurance and searches, which add considerable burdens on such transfers in the United States that the Doing Business reports ignore.

These problems can, perhaps, be remedied if studies take more seriously the possibility of functional equivalents. ${ }^{58}$ However, limits to the method remain. Functionalist comparative law has been criticized for its reductionism and its inability to provide thick descriptions of legal systems. ${ }^{59} \mathrm{I}$ do not think that the functional method, understood (as it should) as a hermeneutical approach to legal systems, is necessarily more reductionist than other methods. ${ }^{60}$ But I do agree that empirical comparative law must ultimately be confined to what can be measured, which means that it cannot capture the full richness of legal systems. Coding as the method of the legal origins literature is necessarily reductionist; its isolation of sin-

54. See, most recently, Richard Hyland, Gifts-A Study in Comparative Law 69-73 (2009).

55. Mathias Siems \& Simon Deakin, Comparative Law and Finance: Past, Present and Future Research 5, 7 (2009), available at ssrn.com/abstract=1428247.

56. Markus Berndt, Global Differences in Corporate Governance Systems (2002), cited after Siems \& Deakin, $i d$, at 6.

57. Michaels, supra note 50, at 205-07, drawing on R.C. van CAEnEgem, Judges, Legislators and Professors: Chapters in European Legal History (1987).

58. Armour et al., supra note 16.

59. Locus classicus is Clifford Geertz, Local Knowledge: Fact and Law in Comparative Perspective, in Clifford Geertz, Local Knowledge: Further Essays in INTERPRETIVE ANTHROPOLOGY 167 (1983).

60. Michaels, supra note 7, at 364-65. 
gle elements represents the polar opposite of thick description. This is not a reason to dismiss coding altogether, in particular insofar as it contributes valuable empirical and experimental knowledge to a functional method in comparative law that is often purely speculative. But it suggests that other approaches will be required as well.

\section{Case Method}

The legal origins literature overlaps not only with functionalist comparative law but also with the case method of common core research. Consider that Djankov et al., in order to measure debt enforcement in various countries, "present insolvency practitioners in each country with the same case study of an insolvent firm" and "then ask each practitioner to describe in detail how debt enforcement for these case facts in his or her country will proceed, step by step." 61 This method of presenting the same case pattern to different legal systems has a parallel in traditional comparative law, where it provides the foundation of studies of the common core of legal systems-first Schlesinger's early project on contract formation, ${ }^{62}$ more recently studies on a common core of European private law. ${ }^{63}$ Parallels abound: both economists and common core researchers rely on the input from legal experts from the respective countries; both use questionnaires that are, where necessary, revised in view of the first responses from these experts. Indeed, Ugo Mattei has explicitly suggested economic analysis as a helpful tool for common core research. ${ }^{64}$

And yet, in the end the differences are more important than the similarities. Methodologically, the common core projects are explicitly legal in nature: Schlesinger was interested in how contracts were formed; the European project is interested in how cases are solved and what legal formants are involved in these solutions. This is not the goal of the legal origins literature, which views legal rules as mere factors in the research of extralegal developments, most importantly the ability to do business and the economic progress of national economies. Whereas the common core research aims at presenting legal systems in all their complexity and internal incoherence among various legal formants, the legal origins literature reduces legal systems to very few factors.

It must be conceded that in terms of influence the common core projects have been far less successful than the legal origins litera-

61. Simeon Djankov et al., Debt Enforcement Around the World, 116 J. PoL. Econ. 1105,1106 (2008). The focus on cases characterizes also the "autopsies" method used by Milhaupt \& Pistor, supra note 47 , at 8-11, 45-46.

62. Formation of Contracts: A Study of the Common Core of Legal Systems

(Rudolf B. Schlesinger ed., 1968).

63. Http://www.common-core.org.

64. Ugo Mattei, Comparative Law and Economics 95-99 (1997). 
ture. Schlesinger's common core did not attract further funding, perhaps because its costs seemed disproportionate to its findings. ${ }^{65}$ The Common Core of European Private Law project has had remarkably little influence on European private law, compared to other projects with far less effort and depth. In the end, the detailed description of commonalities and differences in comparative law, coupled with the explicit rejection of any evaluation, has not been a great success story. Perhaps David Kennedy is right when he speculates that "[p]ost-war comparatists seemed determined to establish a professional practice more earnest and boring than many of them could actually stand to pursue."66 Legal origins and Doing Business reports are more successful in part because of their strong normative element. But they also showcase another advantage from which comparative lawyers may learn: the ability to present the very detailed and rich findings in a very accessible, statistical form. ${ }^{67}$ This need not mean that comparative lawyers must adopt statistics. But it suggests that one quality of comparative law, namely its emphasis on description and detail, can quickly turn into a shortcoming as regards effectiveness.

\section{B. Legal Families and the Civil/Common Law Divide}

A core element of the legal origins thesis is the distinction between the civil and common law families. This distinction plays multiple roles. First, membership in a legal family is viewed as an explanatory factor, as a cause for past and present economic development. Second, legal families are evaluated on the basis of their economic performance: the common law comes out, by and large, as superior. Third, legal families are used as models for law reform. All of this makes it worthwhile to relate LLS' use of legal families to comparative law knowledge.

\section{The Division of Legal Families}

LLS allocate legal systems to either the civil or the common law family. Critics have pointed out that the way in which LLS assign legal systems to one or the other legal family is crude and often faulty. ${ }^{68}$ In addition, "all legal systems are mixed." 69 Even if defined

65. Ulrich Drobnig, Memorial Address for Rudolf Schlesinger: Delivered at the University of Trento Law School, 21 Hastings InT'L \& CoMP. L. REv. 765, 769 (1998).

66. David Kennedy, The Methods and the Politics, in Comparative Legal Studies: Traditions and Transitions 345, 351-52 (Pierre Legrand \& Roderick Munday eds., 2003).

67. See Spamann, supra note 11, at 804-06.

68. E.g., Mathias Siems, Legal Origins: Reconciling Law \& Finance and Comparative Law, 52 McGill L.J. 55, 65-70 (2007). Indeed, the CIA World Factbook that LLSV used can hardly be called a typical comparative law source.

69. Esin Örücü, A General View of 'Legal Families' and of 'Mixing Systems,' in Comparative Law: A Handbook 169, 177 (Esin Örücü \& David Nelken eds., 2007). 
in the narrow sense as systems with both common and civil law influences, mixed systems are the norm rather than the exception. Influences from continental legal thought on English common law and on U.S. law have been researched extensively; the counterinfluence from common law on civil law is a little less well-researched but certainly exists. ${ }^{70}$ Moreover, especially in non-Western countries, Western law has often mixed with domestic legal traditions, resulting in mutual influence. ${ }^{71}$

In essence, LLS are not interested in all legal families but only two: common law and civil law (and within the latter usually just French-law based systems). Although the civil/common law divide has been borrowed from comparative law and represents, for some, still the core of our field, its use is quite problematic. In comparative law, we have come to think that the civil law/common law distinction is no longer very relevant for most important questions ${ }^{72}$ and especially less important than that between the law of developed and that of developing nations: the laws of developed capitalists economies are converging to a large degree, while the laws in many developing countries are still deficient. France may be a close neighbor of Azerbaijan in the rankings; but their economies (and their laws) are like apples and oranges in almost every way. The difference between civil and common law seems especially irrelevant, as critics have pointed out, for most of the areas of economic law researched by the legal origins literature. ${ }^{73}$ Yet, the civil/common law divide does remain relevant for civil procedure, which is still different among these legal families. ${ }^{74}$ And the two explanations for the impact of legal origins on economic development ${ }^{75}$ - greater independence of common law judges and greater adaptability of the common law-are both grounded in differences of procedure. This makes it important for comparative lawyers to address the plausibility of these two theses in

70. An extensive literature looks at the influence of U.S. law, though rarely with an emphasis on its role as a common law system. For a brief survey with references, see Ralf Michaels, American Law (United States), in Elgar Encyclopedia of ComPARATIVE LAW 66, 73-74 (Jan Smits ed., 2006).

71. A telling example is Donald Horowitz, The Qur'an and the Common Law: Islamic Law Reform and the Theory of Legal Change (pts. 1 \& 2), 42 Aм. J. Comp. L. 233, 543 (1994).

72. Reinhard Zimmermann, Der europäische Charakter des englischen Rechts: Historische Verbindungen zwischen civil law und common law, 1 ZEUP 4 (1993); James Gordley, Common law und civil law: eine überholte Unterscheidung, 1 ZEuP 498 (1993). But see Pierre Legrand, The Same and the Different, in Comparative LeGAL STUDIES, supra note 66 , at 240.

73. Detlev Vagts, Comparative Company Law-The New Wave, in Festschrift für Jean Nicolas Druey zum 65. Geburtstag 595, 599 (2003).

74. See only Oscar G. Chase et al., Civil Litigation in Comparative Context (2007).

75. Supra, at 769. 
particular. Lawyer-economists have taken this on; ${ }^{76}$ comparative lawyers should make sure that our (considerable) expertise in this area is used to refine or refute the assumptions in the economics literature. ${ }^{77}$

\section{The Use of Legal Families}

The more important criticism concerns not how legal systems are allocated to legal families but how the idea of legal families is used more generally. Comparative lawyers see their value now as mainly didactic, ${ }^{78}$ fluid, ${ }^{79}$ and context-dependent. ${ }^{80}$ Hein Kötz has persuasively argued that legal families help beginners, but the interesting questions are elsewhere. ${ }^{81}$ By contrast, LLS take legal families as hard data. Thus, they invoke Zweigert \& Kötz's idea that legal systems can be distinguished by their ideology, although Zweigert and Kötz explicitly reject this criterion for the distinction between civil and common law. ${ }^{82}$ LLS adopt Damaska's distinction between civil law as "policy implementing," and common law as "dispute resolving,"83 even though Damaska uses these descriptions merely as Weberian ideal types and has warned explicitly that "characteristics of the two archetypes should not be understood as repositories of essential facets of existing procedures in civil- and common-law countries." 84

In the view expressed in the legal origins literature, legal families are also constant over time. After the original claim that differences between common law and civil law were developed in the twelfth century proved to be untenable, the authors of the legal ori-

76. Gillian Hadfield, The Levers of Legal Design, 36 J. Comp. Econ. 43 (2008); Bernd Hayo \& Stefan Voigt, Explaining de facto Judicial Independence, 27 INT'L REv. Law \& Econ. 269 (2007); Bernd Hayo \& Stefan Voigt, The Relevance of Judicial Procedure for Economic Growth, 27 INT'L REv. L. \& Econ. 269 (2007).

77. This year's conference of the International Association of Procedural Law in Toronto was dedicated to the topic.

78. Similarly Siems, supra note 68 , at 69 . See Zweigert \& Kötz, supra note 7 , at 73; René David \& John E.C. Brierley, Major Legal Systems in the World Today 21 (1985).

79. Zweigert \& Kötz, supra note 7, at 66-67; Jaako Husa, Classification of Legal Families Today. Is it Time for a Memorial Hymn?, 2004 REv. INT. Dr. CoMP. 11, 14-16 (2004).

80. Zweigert \& KöTZ, supra note 7, at 65-66.

81. Hein Kötz, Abschied von der Rechtskreislehre?, 6 ZEuP 495 (1998); Hein Kötz, Rechtskreislehre, in II Handwörterbuch zUm eUropäischen Privatrecht 1247, 1248 (Jürgen Basedow, Klaus Hopt, Reinhard Zimmermann eds., 2009), English translation forthcoming.

82. Compare La Porta et al., supra note 17, at 286-87, with Zweigert \& Kötz, supra note 7 , at 72 .

83. La Porta et al., supra note 17 , at 286.

84. Miruan Damaska, The Faces of Justice and State Authority 12 (1986). Similarly for legal families as Weberian ideal types Jaako Husa, Legal Families and Research in Comparative Law, Global JuRIst Advances Vol. 1 Issue 3 Art. 4 (2001), available at http://works.bepress.com/jaakko_husa/1. 
gins thesis now situate the divergence in the seventeenth through nineteenth centuries. ${ }^{85}$ Ultimately, the point in time is irrelevant to their claim that after the divergence occurred, the styles became constant. That claim is unpersuasive. It is unclear why legal systems can change dramatically at one point in time and then remain impervious to further change. It is also unclear how both the colonial imposition explanation and the policy recommendations in the Doing Business reports are compatible with the idea of an unchanging legal tradition. But most importantly, the idea of an unchanging legal character appears incompatible with comparative law knowledge. Most comparative lawyers oppose the idea that a country's legal system is static, which is why we now prefer the dynamic notion of "legal tradition" over that of "legal family." 86 There is certainly some type of continuity that may be expressed in economic terms as path dependency which means that different legal systems will respond differently to common developments. But this is quite different from claiming perpetual characteristics.

In emphasizing an ultimately inalterable difference between civil and common law as the most important distinction, the legal origins literature ironically parallels the views of one of the most outspoken critics of comparative law and economics, Pierre Legrand. ${ }^{87}$ Both may well be correct that we comparative lawyers have overestimated the convergence between civil and common law as well as the adaptability of both legal systems. The legal origins literature would then provide helpful empirical data that may suggest a persistent distinction between the political economies of civil and common law countries with strong historical roots. 88 This would only be proven, however, if the measurements and evaluations were performed accurately, and that is doubtful, as discussed in the next subsection.

\section{Commensurability and Evaluation}

A major reason for the great success of both the legal origins thesis and the Doing Business reports lies in their strong normative comparative conclusion: common law as better for economic progress than civil law. In the legal origins thesis, the conclusion is still presented as descriptive and also modified (though only slightly); the Doing Business reports by contrast are quite openly evaluative. Al-

85. La Porta et al,. supra note 17 , at 303-06.

86. Reimann, supra note 45 at 677-78 (2002); H. Patrick Glenn, Comparative Legal Families and Comparative Legal Traditions, in The Oxford HandBook of Comparative Law, supra note 7 , at 421, 437-39.

87. Pierre Legrand, Econocentrism, 59 U. Toronto L.J. 215 (2009). Legrand was not always so opposed to comparative law and economics; see Pierre Legrand, Jr., PreContractual Disclosure and Information: English and French Law Compared, 6 Ox. J. LEG. STUD. 322, 343-5 (1986).

88. Thus John Reitz, Legal Origins, Political Economy, and the Problem of Generalization, 57 Ам. J. Comp. L. 847 (2009). 
though comparative lawyers endorse such evaluative comparison when they discuss regulatory competition (an idea borrowed from economists), by and large, they despise comparative evaluation is incompatible with their main goal of pure knowledge. ${ }^{89}$ Essentially, there are two reasons for this unease with evaluation: the problem of commensurability and the risk of homeward bias.

\section{Regulatory Competition}

One way in which economics has long been used in traditional comparative law is in the discussion of regulatory competition. Jan Smits has argued for such competition as a bottom-up approach towards private law unification in Europe; 90 Anthony Ogus views such competition as a useful generator of information for law reform. ${ }^{91}$ However, the use of economics in this context is quite a bit looser than in its original formulation. In many studies, regulatory competition is more a rhetorical figure than an actual economic model, ${ }^{92}$ a starting point for more conventional comparative law analysis. More often than not, competition of legal systems is used as a mere toolbox for legislators; the idea that legal systems themselves truly compete is not shared by many comparatists. The Doing Business reports, by contrast, emphasize precisely such competition, especially competition for private investors. At the same time, they show some of the problems of such competition. First, in making explicit policy recommendations, the Doing Business reports interfere in the "market for laws"93 that they set out to measure. Second, the emphasis on ease of doing business at the expense of other policy considerations, for example, employee protection, presents the well-known risk of a "race to the bottom;" as reactions at the World Bank show, this risk is being recognized. ${ }^{94}$ The recent adoption of other values beyond efficiency ${ }^{95}$ presents an unintentional approximation to comparative law's emphasis on more holistic comparison.

89. See discussion and references in H. Patrick Glenn, Aims of Comparative Law, in Elgar EnCyClopedia of Comparative Law, supra note 70, at 57, 58-89.

90. Jan Smits, European Private Law: A Plea for a Spontaneous Legal Order, in European Integration and Law 55 (D.M. Curtin et al. eds., 2006).

91. Ogus, infra note 138.

92. See Eva-Maria Kieninger, Wettbewerb der Privatrechtsordnungen im EUROPÄISCHEN BINNENMARKT (2002).

93. Erin O'Hara \& Larry E. Ribstein, The Law Market (2009); $c f$. Milhaupt \& PISTOR, supra note 47, at 213 ("commodification of law"); Eidenmüller, supra note 33.

94. See supra 774-75.

95. Supra, 775. 


\section{Relativity}

Commensurability is a key prerequisite for comparability and therefore a key issue in comparative law. ${ }^{96}$ Comparison requires a tertium comparationis: we always compare legal systems with regard to a specific factor, be it the performance of a certain function or something else. It follows that findings of similarity and difference are always relative to the specific tertium that was chosen. Absolute comparison is impossible. This is even more true for determining the better law: a law can be better than another only with regard to the specific function they both perform. Comparative lawyers have become cautious in evaluating one law as better than another. Some object to any evaluative comparison on the basis of incommensurability. Yet, even those who see value in it are hesitant, and for a reason: if both laws are functionally equivalent they are by definition of equal value with regard to that specific function. "The specific function itself cannot serve as a yardstick, for functionally equivalent institutions are by definition of equal value with respect to that function-equivalence means, literally, of equal value."97 Differences may occur only outside of that function: their ability to perform other functions, their costs, etc. ${ }^{98}$

The legal origins literature accepts this restriction, as do the Doing Business reports. However, in the presentation, the relative character of the comparison drops out of sight. This may be the biggest problem with the ranking of countries in the Doing Business reports: they suggest a ranking with regard to the absolute quality of legal systems, and they thereby put pressure on countries to focus their domestic policies on the factors that the Doing Business report measures-and to neglect other functions of the law. ${ }^{99}$ It appears as though the common law is better than the civil law tout court, instead of only in promoting economic growth. ${ }^{100}$

Of course, this reductionist quality of rankings is an advantage for their marketability. Rankings are simpler than complex comparisons. It is precisely this simplicity that makes them suspicious from a comparative law perspective. At the same time, we comparative lawyers may need to ask ourselves whether we have not gone too far in

96. See Nils Jansen, Comparative Law and Comparative Knowledge, in THE OxFORD HANDBOOK OF COMPARATIVE LAW, supra note 7, at 305.

97. Michaels, supra note 7 , at 374 .

98. See Michaels, supra note 7, at 374-76.

99. See Bjørn Høyland et al., The Tyranny of International Index Rankings (2009), available at http://folk.uio.no/bjornkho/TyrannyIndexRankingsHoylandMoeneWillum sen.pdf. In the United States, a similar problem is known from the ranking of law schools, which appears to measure the objective quality of law schools and therefore creates strong incentives for law schools to improve rankings, not law schools. See only Michael E. Solimine, Status Seeking and the Allure and Limits of Law School Rankings, 81 IND. L.J. 299 (2006).

100. Cf. Jansen, supra note 96, at 312-14. 
our refusal to evaluate and in our emphasis on incommensurability. Some of the most influential studies in comparative law-Langbein's study of German civil procedure, Damaska's analysis on court structures, James Whitman's studies on dignity-all present theses that are, on their face, much too crude and simple and have since been refined by subsequent writing. Yet their very simplicity was what got the respective discussions going; it is therefore their strength, not their weakness, and perhaps a strength that comparative law needs in order to keep up with economics.

\section{Objectivity}

An additional problem in the comparative evaluation of legal systems is homeward bias. Every comparative lawyer knows the risk that she may unknowingly favor her own law simply because she knows it better; opinions differ merely over whether this homeward bias can be overcome or whether we are necessarily stuck within the mentality of our own legal system. Such homeward bias can come in two variants. The first, perhaps more obvious variant, can be called solution bias: the prioritization of our own system's solutions over those of other countries simply because we know them better and have internalized them. This is the core bias of domestic lawyers that comparative lawyers try to overcome. The legal origins literature and the Doing Business reports promise to overcome these problems and to provide true neutrality, though they are only partially successful. They do provide a very helpful remedy against solution bias: the use of empirical data and measurements. ${ }^{101}$ Traditional comparative lawyers have a lot to learn here.

However, homeward bias can also come in a more subtle variant that we may call question bias. It concerns not the solutions we find but the questions we ask. Because we think within the framework of our own legal system, we tend to ask questions posed by our own system-and in many cases find that our own legal system provides the better answers, simply because our legal system responds precisely to these questions. The only way to overcome this bias is dialogue with comparatists from other legal systems who may be able to point out that questions that work in one framework make little sense in another. The legal origins literature is less successful in overcoming question bias. Authors may point out that they are not lawyers, so they cannot (one would hope) be biased in favor of one legal system's inherent rationality over the other. The questions they ask are economic, not legal, in nature. Yet, rather than overcoming the problem, that exacerbates it. First, it leads to a bias not for one legal system over another but for one discipline over another, something that may

101. I ignore here critique of how accurate the data is; see WORLD BANK INDEPENDENT Evaluation, supra note 34, at 13-17. 
be called economics bias. ${ }^{102}$ Moreover, because the economics used in these projects is primarily U.S.-American in origin and has been developed with U.S. law in mind, the bias for economics turns quite easily into a bias for U.S. law. The emphasis on shareholder rights, to name but one example, reflect exactly one such bias. In other words, the good performance of the U.S. and other common law systems is a direct consequence of the questions asked.

\section{Legal Transplants}

Legal transplants-the transfer of legal norms and institutions from one legal system to another-have two roles to play in the legal origins literature. The first is descriptive and explanatory: the imposition of Western laws on nonwestern countries in the course of colonization is viewed as an explanatory factor for economic progress in these colonies. The second role is normative: the export of common law norms and institutions is recommended as a way to improve economic performance. Both link up with traditional comparative law.

\section{Colonization}

Although the export of European legal systems in the nineteenth century is a well-known topic in traditional comparative law, the political aspects of colonialism are often downplayed. ${ }^{103}$ Ironically, the violence of colonization becomes a virtue for the legal origins literature: the assumption that laws were imposed on the colonies without indigenous choice makes it possible to treat law as an exogenous factor. Unfortunately, the image of transplantation of laws is seriously deficient from a comparative law standpoint. Transplantation was more complex in colonization and post-colonization than presented by LLS $^{104}$ and it is more complex now. We know that the transplantation of laws does not leave these laws unchanged: transplanted laws function more like legal irritants, creating internal developments within the importing legal systems. (Only Alan Watson agrees that laws remain unchanged in the process of transplantation, but he would violently dispute the core assumption of the legal origins literature that such laws have a significant impact on society and the

102. This is the core of the French critique against the Doing Business reports. See Fauvarque-Cosson \& Kerhuel, supra note 29.

103. Upendra Baxi, The Colonialist Heritage, in Legrand \& Munday, supra note 66 , at 59 .

104. For English law, see B. H. McPherson, The Reception of English Law ABROAD (2007); for French Law, see L'INFLUENCE INTERNATIONALE DU DROIT FRANÇAIS, RAPPORT DU Conseil D'Etat (Oliver Dutheillet de Lamothe \& Marie-Aimé Latournerie eds., 2001), available at http://www.ladocumentationfrancaise.fr/rap ports-publics/014000702/index.shtml. 
economy.) ${ }^{105}$ We know (as LLS now concede) that the transplantion of formal laws cannot succeed unless it comes with the transport of legal expertise. We know that legal export is not successful without what Katharina Pistor and others have called, in explicit response to the legal origins literature, the demand for law ${ }^{106}$ and what Otto Kahn-Freund identified long ago as the relevance of local interest groups that are pushing for its adoption. ${ }^{107}$

Despite all this, the legal origins thesis remains highly interesting for comparative law. Traditionally, we might have thought that the civil law should travel more easily than the common law, because its reliance on systematized codification requires less expertise in the recipient country; the situations in England with its traditionally homogenous culture and the United States with its peculiar role for the law as a motor of social change are not easy to replicate. If LLS are correct that common law colonies developed better economically than civil law colonies, this raises the very important question whether the relevant difference lies in legal systems or in some other factor. One plausible explaining factor could be the British practice of indirect rule that empowered local elites and thereby enabled the colonies, especially after independence, to rely on local structures and institutions and indigenous expertise, an important advantage over French colonies that had to build such expertise from scratch. ${ }^{108}$

\section{Law Reform}

The legal origins thesis gets its bite not from using colonization as an explanatory factor but from the normative implications made explicit in the Doing Business reports: countries will perform better today if they adopt common law structures than if they adopt civil law structures. The Reports share this interest in improving law with traditional comparative law, though with a twist: traditional comparative lawyers have long focused mainly on the improvement of their own law; 109 the Doing Business reports, like the World Bank generally, aims primarily at improving the law elsewhere. In other words,

105. See Alan Watson, Society and Legal Change (2d ed. 2001). See also, now, Holger Spamann, Contemporary Legal Transplants - Legal Families and the Diffusion of (Corporate) Law, 2009 (6) BYU L. REV. (forthcoming, Dec. 2009).

106. David Berkowitz et al., The Transplant Effect, 51 AM. J. Comp. L. 163 (2003); Milhaupt \& Pistor, supra note 47, at 201-12.

107. Otto Kahn-Freund, On Uses and Misuses of Comparative Law, 37 Mod. L. REv. 1, 12-13 (1974).

108. Cf. Sandra Fullerton Joireman, Inherited Legal Systems and Effective Rule of Law: Africa and the Colonial Legacy, 39 J. of Mod. Afr. Stud. 571, 579-81 (2001). However, for evidence that indirect rule colonies had higher rates of instability, see Matthew K. Lange, British Colonial Legacies and Political Development, 32 WorLd DeVELOPMENT 905 (2004).

109. E.g. David \& Brierley, supra note 78, at 6-8; LÉontin-Jean Constantinesco, Rechtsvergleichung I-Einfunhung in DIe ReChtsvergleichung 371-73 (1971); Zweigent \& KötZ, supra note 7, at 16-20. 
what is at stake here is not so much the import of law but rather the exportation of Western laws (primarily those from common law countries) to nonwestern countries. This may be one explanation for the "one size fits all" approach in the early Doing Business reports: the thought that what matters in law reform can be determined by finding the best law and then exporting it, rather than focusing on local conditions and the best "fit" as comparative lawyers would argue.

This does not make the studies meaningless. The focus on the best fit is not confined to import; it is relevant to the export of law as well. The importing country may not even always be better equipped to determine the best fit than an outside observer; outside observes can sometimes provide a fresh and helpful perspective on what might make sense as reform. This means, however, that traditional comparative lawyers may want to make their voices heard more prominently in law reform projects. They can bring their special expertise in "best fit" to the table. The Japanese approach to legal assistance, which emphasizes such local requirements of "fit" and local demands, provides an interesting example of such an approach. ${ }^{110}$ The World Bank and the IMF may prove to be open to such approaches more based in comparative law as well. ${ }^{111}$

\section{E. Culture}

The main criticism voiced especially by French lawyers against the Doing Business reports is their neglect of culture. ${ }^{112}$ This criticism is representative of the recent cultural turn in comparative law, ${ }^{113}$ a trend in turn favored by the unclear concept we comparative lawyers have of culture. ${ }^{114}$ In France, one author has gone so far as to dismiss law and economics as an idiotic science. ${ }^{115}$ In reality, the conflict of culture and economics is less clear-cut.

First, different research questions make different aspects relevant or irrelevant. The legal origins literature is interested in the connection between law and economic progress, not in the connection between law and values or law and culture. It is not clear why research into the relation between law and economic progress, which is certainly not irrelevant, must necessarily include culture. Arguably,

110. Shuya Hayashi, The Search of Knowledge. Some Perspectives in Legal Assistance in Developing Economies (unpublished paper, 2009).

111. See Milhaupt, supra note 4, last paragraph.

112. See Fauvarque-Cosson \& Kerhuel, supra note 29.

113. Roger Cotterell, Comparative Law and Legal Culture, in The Oxford HandвоOK of Comparative Law, supra note 7, at 709; David Nelken, Defining and Using the Concept of Legal Culture, in Comparative Law: A HandBook, supra note 69, at 109.

114. Ralf Michaels, Rechtskultur, in HANDwörterbuch zum EuropäIschen PrivaTRECHT, supra note 81 at 1249 (2009); English translation forthcoming.

115. Alain Bernard, Law and Economics, une science idiote?, 2008 RECUEIL DALLOZ 2806. 
although a proper understanding of local culture is necessary for successful law reform, an overemphasis on culture holds us back in achieving progress in the law altogether. For example, the fear of comparative lawyers that Western laws are incompatible with African values and culture tends to disregard that Africans may in fact want to reap the benefits of taking part in Western culture-especially so after globalization has already made it impossible for them to live some autochthonous culture in isolation from the rest of the world. The French emphasis on culture as against the Doing Business reports could be viewed as mere protectionism, were it not coupled with projects to show that French law actually does perform better than is claimed. ${ }^{116}$

Second, culture need not be anathema to economic analysis. ${ }^{117}$ From an economic perspective, culture can be conceptualized as an informal constraint, ${ }^{118}$ or as path dependency. Anthony Ogus has explained culture as an obstacle to regulatory competition. ${ }^{119}$ Most economists, however, take a more neutral position: they try to measure cultural preferences in different societies as one factor that will determine what kind of legal system is most appropriate. ${ }^{120}$ In a recent paper, a number of American and French economists (among them one of the legal origins authors) try to demonstrate an interrelation between high degrees of regulation and a high level of mutual distrust in society: the more people distrust each other the more they rely on regulation, and the more they invoke regulation the more they create distrust in society. ${ }^{121}$ At the end of their essay they address the relation between their paper and the legal origins thesis and thus the question of how law and culture interrelate. We may (and should) question whether economics gets culture right, but it would be an exaggeration to think that economics leaves no place for culture.

The problem with the absence of culture in the legal origins literature is more indirect. Although culture need not figure in each project and although it can theoretically be conceptualized in economic terms, the fact that the debate about law reform is held in economic terms means in fact that cultural specificities tend to be

116. Fauvarque-Cosson \& Kerhuel, supra note 29, at 818-19.

117. Similarly Pierre Legrand, Book Review, 56 CAM. L. REv. 638, 640 (1997) (but see now Legrand, supra note 87). More generally, see Eelke DE JonG, Culture AND Economics-On Values, Economics and International Business (2009).

118. Douglas North, Institutions, Institutional Change and Economic PerFORMANCE 36-45 (1990).

119. Anthony Ogus, The Economic Basis of Legal Culture: Networks and Monopolization, 22 Ox. J. OF Legal Stud. 419 (2002).

120. See, especially, Amir Licht et al., Culture Rules: The Foundations of the Rule of Law and other Norms of Governance, 35 J. of Comp. Econ. 659 (2007).

121. Philippe Aghion et al., Regulation and Distrust, available at http://ssrn.com/ abstract $=1324264$. 
disregarded. Coding does not lend itself easily to proper understanding of culture. This is true for the cultures in recipient countries, especially insofar as early Doing Business reports proclaimed a "one size fits all" approach. Yet it is true also, and perhaps even more importantly, for the culture of donor countries and the cultural contingencies of their laws. ${ }^{122}$ One of the core goals of comparative law is understanding our own law-and culture-in relation to other laws. U.S. law is often declared to be exceptional, without real comparison to back up this claim. The legal origins literature favors the opposite extreme: U.S. law is established as the benchmark, the goal of legal convergence, the end of (legal) history. Comparative lawyers retain the task to highlight the cultural contingency also of U.S. law and its constructs-and of the particular approach to comparative law as established in the legal origins literature. ${ }^{123}$

At the same time, however, the legal origins literature may provide a healthy antidote to the risk of overemphasis on legal culture in comparative law. Often, we use legal culture as a fancy and conveniently imprecise shorthand for all kinds of aspects we cannot or do not want to express more explicitly. Studies that ignore culture or, worse, operationalize it in the way the legal origins literature does, pressure us to express more precisely what we mean by culture and why we think economists do not account for it accurately. Such pressure can only be helpful for comparative law.

\section{Conclusion: The Specific Knowledge of Comparative Law}

What follows from all of this for the relation between comparative law and economics? A first response would be the prediction or even promotion that economics now replaces comparative law. The authors of the legal origins literature would then have made true for comparative law what Justice Holmes famously proclaimed almost exactly one hundred years earlier, in 1897, namely that "the man of the future is the man of statistics and the master of economics."124 The amazing political success of both the legal origins thesis and the Doing Business reports may suggest as much, especially when compared with the declining political importance of comparative law, ${ }^{125}$ at least outside European private law harmonization. ${ }^{126}$ However,

122. Of course, the economic approach itself represents a particular culture as well.

123. On this, see Vivian Grosswald Curran, Comparative Law and the Legal Origins Thesis: "[N]on scholae sed vitae discimus," 57 Aм. J. Comp. L. 863 (2009).

124. Oliver Wendell Holmes, The Path of the Law, 10 Harv. L. REv. 459, at 469 (1897).

125. Mathias Siems, The End of Comparative Law, 2 J. Comp. L. 133 (2007); see already Ralf Michaels, Im Westen nichts Neues, 66 RABELSZ 97, 112-15 (2002); Reimann, supra note 45 , at $685-90$.

126. On European private law as a success story of comparative law, Reimann, supra note 45, at 690-95; on the limited role of comparative law as only one of the 
such demise of comparative law in favor of economics is unlikely. First, comparative law will maintain an important role outside the instrumentalism of politics and law reform, a role that economics and the social sciences will not challenge. Second it can already be observed that the economic approach to legal origins depends on better comparative law understanding. The fear of comparative law's demise is a sign more of the field's own perpetual angst than of the threat from other disciplines. ${ }^{127}$ At least, comparative law should survive as a necessary basis for the new comparative economics.

The opposite response would be to dismiss the legal origins literature as so seriously deficient from a comparative law perspective that it is irrelevant for comparative lawyers. This would be exaggerated, too. To some extent such deficiencies are not surprising, given that the legal origins literature is explicitly economic, not legal in its focus. Moreover, within the discipline of economics, an intensive debate is ongoing on the specific economic values and shortcomings of the literature. ${ }^{128}$ This debate connects with the broader debate within economics whether the reductionism of neoclassical economics, which underlies the legal origins literature, should not be at least supplemented with other methods. ${ }^{129}$ And this debate, in turn, suggests that some of the concerns of comparative lawyers find their parallels in economics; thus a conversation should be possible. On the one hand, even good economics will hardly ever be good legal analysis (just as good legal analysis does not amount to good law), because economics answers different questions and uses different methodological tools. ${ }^{130}$ On the other hand, economics must be of interest to us comparative lawyers precisely because these different questions and tools enrich our own perspective. The newly reemerged interest of economists in law is something we comparative lawyers should cherish and support, not dismiss.

This suggests a third response: stronger interdisciplinarity between economics and comparative law. Such interdisciplinarity has a longer tradition than is often acknowledged. Three years prior to the publication of Justice Holmes' quote about the man of the future, ${ }^{131}$ economists and lawyers had founded an "International Association of

factors in European private law, Reinhard Zimmermann, Comparative Law and the Europeanization of Private Law, in The Oxford HandBook of Comparative Law, supra note 7, at 539, 577-78; Ralf Michaels, Rechtsvergleichung, in HANDwÖRTERBUCH ZUM EUROPÄISCHEN PRIVATRECht, supra note 81, at 1260; English translation forthcoming.

127. Curran, supra note 123.

128. See the references in La Porta et al., supra note 17; see also Kenneth Dam, The Law-Growth Nexus: The Rule of Law and Economic Development (2006).

129. For one such proposal, see Tony Lawson, Reorienting Economics (2003).

130. See Ralf Michaels, Economics of Law as Choice of Law, 71 L.\&ContemP. Probs. 73 (2008).

131. Holmes, supra note 124. 
Comparative Legal Science and Economics" in Berlin, the predecessor of today's German Comparative Law Association. ${ }^{132}$ Much of the organization's inaugural article still holds true today: "If now, as is appropriate, lawyers and economists will carry the bulk of the work necessary for further regulation of social conditions, they must step out of their national isolation and join forces in international associations."133 The article expressed the need for comparative law and comparative economics to join forces in order to improve general welfare in the world. Admittedly, little of this proximity between economics and comparative law has remained. In the United States, the neoclassical law and economics of the Chicago school that has come to dominate law and economics is, in its abstraction, largely ahistorical and noncomparative. ${ }^{134}$ In Europe, legal scholarship in general has become anathema to economic theory altogether (a difference to the United States that has led to lots of speculation about the reasons). ${ }^{135}$ A puzzling amnesia has eradicated almost all memory of European law and economics around the turn of the nineteenth century; law and economics is now almost exclusively viewed as an import from the United States. ${ }^{136}$ Most importantly for this essay, current comparative law on both sides of the Atlantic Ocean is almost completely devoid of economics. The leading coursebooks do not mention it at all (and none, curiously, address the legal origins literature). ${ }^{137}$ Comparative Law encyclopedias contain chapters, but none is really comprehensive. ${ }^{138}$ And the three-volume collection on

132. Elmar Wadle, Einhundert Jahre Rechtsvergleichende Gesellschaften in Deutschland 32-42 (1994).

133. Franz Bernhöft, Unser Zweck, 1 JAHRBuch DER Internationalen VerEINIGUNG FÜR VERGLEICHENDE RECHTSWISSENSCHAFT UND VOLKSWIRTSCHAFTSLEHRE ZU BERLIN 1, 12 (1895).

134. Ron Harris, The Uses of History in Law and Economics, 4 Theoretical INQUIRIES IN LAW 659, 666-74 (2004). But see the occasional comparative remarks in Steven Shavell, Foundations of Economic Analysis of Law 55, 164-65, 204-05, 223, 243, 247, 249, 267 (2004).

135. Christian Kirchner, The Difficult Reception of Law and Economics in Germany, 11 InTERNATIONAL REVIEW OF LAW AND ECONOMICS 277 (1991); Viktor Winkler, Review Essay-Some Realism about Rationalism: Economic Analysis of Law in Germany, 6 German L.J. 1033 (2005); Oren Gazal-Ayal, Economic Analysis of Law in North America, Europe and Israel, 3 REv. L. \& Econ. Issue 2 article 11 (2007), available at http://www.bepress.com/rle/vol3/iss2/art11; Kristoffel Grechenig \& Martin Gelter, The Transatlantic Divergence in Legal Thought: American Law and Economics vs. German Doctrinalism, 31 Hastings Int'L \& Comp. L. Rev. 295 (2008); Nuno Garoupa \& Thomas S. Ulen The Market for Legal Innovation: Law and Economics in Europe and the United States, 59 AlA. L. REv. 1555 (2008).

136. E.g. Roland Kirstein, Law and Economics in Germany, in I ENCYCLOPEDIA of LAW AND ECONOMICs 160 (B. Bouckaert \& G. de Geest eds., 2000), available at http:// encyclo.findlaw.com/0330book.pdf. But see Viktor Winkler, Ökonomische Analyse des Rechts im 19. Jahrhundert: Victor Matajas "Recht des Schadensersatzes" revisited, 26 ZeITSChrIFt FÜr NeUere ReChtSGEschichte 262 (2004).

137. One exception is now Ugo A.Mattei et al., Schlesinger's Comparative Law. CAses-TeXt-Materials 13-31, 267 (7th ed. 2009).

138. Florian Faust, Comparative Law and Economic Analysis of Law, in THE OxFord HandBook of Comparative Law, supra note 7, at 837; Raffaele Caterina, 
"Comparative Law and Economics" (2004) is symptomatically edited by two law and economics scholars and contains mainly articles by economists. ${ }^{139}$

The legal origins literature provides a welcome incentive for renewed interdisciplinarity between economics and comparative law. The previous section has shown several avenues for such fruitful interdisciplinarity. A project centered at the University of Cambridge takes such input from comparative law to heart. The project, which combines lawyers and economists, aims for better measurements of law's effect on economics by working with a more accurate understanding of laws and of functional equivalents. ${ }^{140}$ And yet, ultimately economics and comparative law will likely remain separate at least to some degree. First, law remains, at some stage, too complex to be measured. ${ }^{141}$ The attraction of economics lies in the reduction of such complexity to manageable data; ${ }^{142}$ the attraction of comparative law, by contrast, lies in the emphasis that law remains, at some stage, irreducibly complex. Second, lawyer-economists tend to take an outside view of the law. Maybe this perspective need not go so far as to view law as ideology, as LLS claim. Nonetheless, the internal perspective of lawyers must likely remain inaccessible to economics as a social science interested in observable data.

This suggests that we comparative lawyers should take up the dialogue with lawyer-economists. We can and should contribute complexity and accuracy to their projects, which may help them towards a more accurate understanding on the actual operation of law and of legal transplants. In turn, we can learn from them about the measurement of empirical facts and about how to simplify and operationalize the results. Even more importantly perhaps, we can learn how to use academic findings towards influencing political and economic decisions. Our criticism of the simplicity and false reductionism of the rankings in the Doing Business reports misses the most important goal of these rankings: to grab attention, especially

Comparative Law and Economics, in Elgar EnCyClopedia of Comparative Law, supra note 70, at 161; Anthony Ogus, The Economic Approach: Competition between Legal Systems, in Comparative Law: A HandBook, supra note 69, at 155 (Esin Örücü \& David Nelken eds., 2007). See also Ugo Mattei \& Fabrizio Cafaggi, Comparative Law and Economics, in I The New Palgrave Dictionary of Economics and the Law 346 (P. Newman ed., 1998); Ugo A. Mattei, Luisa Antoniolli and Andrea Rossato, Comparative Law and Economics, in I ENCYCLOPEDIA OF LAW AND ECONOMICS, supra note 136 , at 505, available at http://encyclo.findlaw.com/0560book.pdf.

139. Comparative Law and Economics (Gerrit De Geest \& Roger Van den Bergh eds., 3 Vols., 2004).

140. Armour et al., supra note 16.

141. Kevin E. Davis \& Michael B. Kruse, Taking the Measure of Law: The Case of the Doing Business Project, 32 L. \& Social Inq. 1095, 1104-05 (2007); Michaels, supra note 50 , at 210-11.

142. Gillian Hadfield, The Strategy of Methodology: The Virtues of Being Reductionist for Comparative Law, 59 U. ToRonTo L.J. 223 (2009). 
when one is talking to lay consumers who want simplifications of the data.

And yet, after all, the challenge from economics forces us to become aware, again, of the specificity of our own knowledge. We have long flirted with the idea that comparative law is "really" not law but something else-comparative sociology perhaps, comparative cultural studies, now perhaps comparative economics. If this were so, then comparative lawyers would ultimately be irrelevant: comparative sociology is better performed by sociologists, economists are better at comparative economics than are comparative lawyers. At the same time, all these disciplines have an inadequate understanding of laws and their comparison. It is this specific legal knowledge of the law that we comparative lawyers have, and in the end, the legal origins literature and the Doing Business reports show how important this specific knowledge actually is. 
